\title{
"Commercial Demonstration of the Manufactured Aggregate Processing Technology Utilizing Spray Dryer Ash"
}

\author{
Quarterly Technical Progress Report
}

Reporting Period: 01/01/2004 through 03/31/2004

DOE Award No: DE-FC26-02NT41421

Date: May 2004

Submitted by:

Universal Aggregates LLC

300 Bursca Drive

Suite 303

Bridgeville, PA 15017

Roy Scandrol, P.E. 


\section{$\underline{\text { Disclaimer }}$}

"This report was prepared as an account of work sponsored by an agency of the United States Government. Neither the United States Government nor any agency thereof, nor any of their employees makes a warranty, express or implied, or assumed any legal liability or responsibility for the accuracy, completeness, or usefulness of any information, apparatus, product, or process disclosed, or represents that its use would not infringe privately owned rights. Reference herein to any specific commercial product, process, or service by trade name, trademark, manufacturer, or otherwise does not necessarily constitute or imply its endorsement, recommendation, or favoring by the United States Government or any agency thereof. The views and opinions of authors expressed herein do not necessarily state or reflect those of the United States Government or any agency thereof." 


\section{$\underline{\text { Abstract }}$}

This quarterly report covers the period from January $1^{\text {st }}, 2004$ through March $31^{\text {st }}, 2004$. It covers: technical development, permitting status, engineering status, construction status, operations summary and marketing support activities for this period. 
Table of Contents

Page

Abstract

i

Executive Summary $\quad$ ii

I) Experimental 1

II) Results and Discussion 1

III) Conclusion 2

IV) References 2 


\section{Executive Summary}

Construction was completed this quarter. The Operation phase began with the hiring and training of operating staff. Startup of the plant began. Minor modifications in operating software and SDA feeding are underway. 
I) Experimental - This section is not applicable to this project.

II) Results and Discussions

This section is broken down into the following subsections: Technical Support, Permitting, Engineering, Construction, Marketing Support, Operations Summary and DOE activities. These subsections describe the activities that have taken place during this quarter as they pertain to this project.

\section{A) Technical Support}

Work on establishing a QA/QC Laboratory next to the aggregate production plant at Birchwood was initiated. The laboratory will be used to monitor qualities of ash, lime and aggregate products, and performance of the aggregate production process. Tests were conducted to evaluate the effects of stockpiled ash aging time on recycle for aggregate production and on other beneficial uses such as road base course and landfill alternative daily cover applications. Extruded products and Proctor samples were prepared for evaluation in geotechnical application. Two curing drums were installed to cure green extruded products directly at the aggregate production plant. The cured extruded products will be crushed to adequate size gradation for ASTM C331 qualification tests to assist marketing of aggregate products during startup.

\section{B) Permitting}

The Virginia DEQ (Department of Air Quality) has been notified that the construction phase is complete.

\section{C) Engineering}

On-going engineering consists of: PLC and data collection system startup. Instrumentation calibration and electronic system tuning.

\section{D) Construction}

Work continues on updating the project punch list as well as the checkout of the mechanical equipment. The truck scale installation is complete as well as the modular office. The mechanical subcontractor has demobilized; the structural subcontractor is completing punch list items. Curing vessel sheeting and roofing is complete and installation of the doors, electrical conduit and insulation is complete. The painter completed work on interior touch up and handrails inside the process building. The general contractor, P. J. Dick Inc. achieved substantial completion effective the end of January. Punch list items and start up assistance continued through the month of February. P. J. Dick de-mobilized in March. The only remaining subcontractor on the property is Casey Industrial, finishing up some electrical punch list items. The Nuclear scale was installed and calibrated, as were the level transmitters in the curing vessel.

\section{E) Marketing Support}

Testing at the National Concrete Masonry Association (NCMA) in Herndon, Virginia was again conducted to establish base - line mix designs with various, potential aggregate buyers (concrete masonry producers) using indigenous aggregates and 
cement. Personal contact was made with several trucking companies for hauling service needs in both aggregate pick up and delivery, and contingency plan hauling. Evaluated costs for possible contingency plan needs in the beneficial use of fixated/conditioned spray dryer ash (structural fill for on-site haul road embankment, structural fill for on-site property development, and road base course application). Initiated visitation and personal contact with ten (10) local landfills in evaluation of possible beneficial use contingency plans (landfills within 100 miles of Birchwood facility). Established plans to conduct "demonstrations" for the beneficial use of fixated/conditioned spray dryer ash for road base course, and alternate daily cover applications in municipal solid waste landfills throughout plant startup, and as required, or when necessary throughout aggregate plant operation. Verified the interest and needs of these landfills to utilize the fixated/conditioned spray dryer ash as a beneficial use product in the event of future production upsets at the aggregate facility (contingency plans).

\section{F) Operations Summary}

Seven technicians were hired. Local credit applications have been submitted to service providers. A tentative start up plan was prepared and initial tests of the pug mill, pug sealer, extruder with SDA and water only were attempted. These start up tests revealed the need for several additional pieces of instrumentation, and water spray nozzles, which were installed. We have been doing minor modifications to the system and have added instrumentation as we progress through the start up process. We were able to extrude a small amount of material at the end of February, but since then we have been overcoming material handling problems. There are a few punch list items yet to be addressed. We have loaded the curing vessel and have recirculated the start-up material. Rick Steele, from J. C. Steele was on site to inspect the operation of the extruder, pug sealer, and pug mill and some modifications have been executed for the pug sealer. Specifically, we are adding single wing pug seal augers, in lieu of the double wing augers. Later in April we will install ones identical to these that are porcelain enamel coated. Contingency plans continue to be developed.

\section{G) $\underline{\mathrm{DOE}}$}

Preparation of the Quarterly Technical Progress Report is underway and was submitted to DOE in February. Supplemental information was obtained and submitted to DOE regarding the Birchwood Budget Period \#3 application. Budget Period \#3 began in February. The Quarterly Progress Report was submitted for the last quarter of 2003.

III) Conclusion - The schedule has been revised for phase III. The activities described in section II will continue into the next quarter.

IV) References - Not applicable for this report. 